\title{
Bone cross-sectional geometry in adult patients with hypophosphatemic rickets: a hip structural analysis study
}

\author{
Signe Sparre Beck-Nielsen ${ }^{1}$, Charlotte Ejersted ${ }^{2}$, Jeppe Gram³ ${ }^{3}$ Kim Brixen ${ }^{1}$ \\ 'Institute of Clinical Research, University of Southern Denmark, Odense, Denmark, \\ ${ }^{2}$ Department of Endocrinology, Odense University Hospital, Odense, Denmark, \\ ${ }^{3}$ Department of Endocrinology, Hospital of Southwest Denmark, Esbjerg, Denmark
}

\section{Introduction}

Rickets is characterized by defect mineralization of bones and growth zones. It is primarily caused by nutritional vitamin $\mathrm{D}$ or calcium deficiency; however, in rare cases rickets is caused by inborn genetic diseases (1). FGF23-associated hypophosphatemic rickets (HR) is a rare disorder caused by mutations in the PHEX gene. HR patients have excessive renal phosphate wasting. In Denmark the incidence is 3,9 per 100000 per year (1). The disease is usually diagnosed within the first years of life by recognition of the clinical signs of rickets: bowing of the weight-bearing extremities, widening of the methaphyses, and growth failure. Adult HR patients have lower final heights mainly due to short legs and often experience joint pain of knee, ankle, and hip especially aged $40+$ years (2).

Martin \& Burr have described how to derive cross-sectional geometry from images acquired from DEXA scanners and the idea has been further developed by Beck et al. into a Hip Structure Analysis (HSA) programme $(3,4)$. The HSA method measures bone geometry in specified regions of the femoral shaft and neck.

The aim of the present study is to evaluate DXA derived hip geometry of adult HR patients using Hip Structure Analysis.

\section{Methods}

Cross-sectional study of adult HR patients $(\mathrm{n}=21)$ at Odense University Hospital compared to age- and sex-matched controls $(\mathrm{n}=38)$. Participants were identified by register search, by contact to HR treating doctors, and family screening (2).

The diagnostic criteria were genetically verified HR by detection of a disease-causing mutation in the PHEX gene and/ or biochemically verified $\mathrm{HR}$ with at least one of the following: serum phosphate below normal range or elevated FGF23. In addition, a history of childhood rickets or spontaneous endodontic abscesses was required to exclude acquired HR as e.g. tumor induced osteomalacia.

Proximal hip DEXA scans were analyzed for bone geometry by use of the HSA programme developed by Beck et al (4) The principle of the HAS method is that a line of pixels across the bone axis is a projection of the corresponding cross-section and measurements of the pixel distribution can be used to estimate its geometry. The analysis included 3 locations: the narrow neck (NN), the intertrocanteric region (IT), and the femoral shaft (FS). Buckling ratio is determined as dmax divided by mean cortical thickness and is considered an estimate of wall stability. CSMI is the integral of area times the distance from center of mass. Section modulus (Z) is calculated as CSMI/ dmax, where dmax is the maximum distance from the center of the mass to the medial or lateral cortical margins.

\section{Results}

\begin{tabular}{|c|c|c|}
\hline & Rickets & Controls \\
\hline $\mathrm{n}$ & 21 & 38 \\
\hline Age (years) & $40,7 \pm 2,4$ & $42,6 \pm 2,3$ \\
\hline Height $(\mathrm{cm})$ & $159,2 \pm 5,5$ & $173,1 \pm 1,8^{*}$ \\
\hline Weight $(\mathrm{kg})$ & $85,7 \pm 5,5$ & $84,2 \pm 2,3$ \\
\hline
\end{tabular}

\begin{tabular}{|c|c|c|}
\hline Narrow neck & Rickets & Controls \\
\hline CSA $(\mathrm{cm})$ & $3,60 \pm 1,06$ & $3,28 \pm 0,70$ \\
\hline${\text { CSMI }\left(\mathrm{cm}^{2}\right)^{2}}^{2}\left(\mathrm{~cm}^{3}\right)$ & $4,06 \pm 1,88$ & $3,63 \pm 1,42$ \\
\hline Section Modulus $\left(\mathrm{cm}^{2}, 04 \pm 0,75\right.$ & $1,86 \pm 0,58$ \\
\hline Buckling Ratio & $9,92 \pm 2,52$ & $10,50 \pm 2,41$ \\
\hline BMD $\left(\mathrm{g} / \mathrm{cm}^{2}\right)$ & $1,06 \pm 0,26$ & $0,98 \pm 0,16$ \\
\hline Shaft neck angle $\left(^{\circ}\right)$ & $124,0 \pm 5,8$ & $130,1 \pm 5,2 * *$ \\
\hline Hip axis length $(\mathrm{mm})$ & $113 \pm 11$ & $114 \pm 12$ \\
\hline
\end{tabular}

\begin{tabular}{|c|c|c|}
\hline Intertrochanteric Region & Rickets & Controls \\
\hline CSA $(\mathrm{cm})$ & $5,99 \pm 0,38$ & $5,44 \pm 0,20$ \\
\hline CSMI $\left(\mathrm{cm}^{2}\right)^{2}$ & $17,13 \pm 1,77$ & $16,4 \pm 1.06$ \\
\hline Section Modulus $\left(\mathrm{cm}^{3}\right)$ & $5,29 \pm 0,46$ & $4,95 \pm 0,26$ \\
\hline Buckling Ratio & $7,20 \pm 0,40$ & $7,89 \pm 0,27$ \\
\hline BMD $\left(\mathrm{g} / \mathrm{cm}^{2}\right)$ & $1,21 \pm 0,59$ & $0,98 \pm 0,03^{*}$ \\
\hline
\end{tabular}

\begin{tabular}{|c|c|c|}
\hline Femoral shaft & Rickets & Controls \\
\hline CSA $\left(\mathrm{cm}^{2}\right)$ & $5,03 \pm 0,27$ & $4,79 \pm 0,16$ \\
\hline CSMI $\left(\mathrm{cm}^{2}\right)^{2}$ & $4,79 \pm 0,42$ & $4,41 \pm 0,27$ \\
\hline Section Modulus $\left(\mathrm{cm}^{3}\right)$ & $2,88 \pm 0,19$ & $2,73 \pm 0,13$ \\
\hline Buckling Ratio & $2,69 \pm 0,15$ & $2,59 \pm 0,09$ \\
\hline BMD $\left(\mathrm{g} / \mathrm{cm}^{2}\right)$ & $1,68 \pm 0,08$ & $1,64 \pm 0,04$ \\
\hline
\end{tabular}

Mean \pm SD , ${ }^{*} \mathrm{p}<0,05, * * \mathrm{p}<0,01$

Cross-sectional area (CSA)

\section{Conclusion}

The HSA analysis of the hip revealed no major differences in geometry between the groups: BMD, CSA, CSMI, section modulus, and buckling ratio were similar between HR patients and sex-and age matched controls. The shaft neck angle and height were lower in HR patients.

\section{References:}

1. Beck-Nielsen SS, Brock-jacobsen B. Gram J, Brixen K, Jensen TK: Eur J Endocrinol 160: 491-497. 2009

2. Beck-Nielsen SS, Brusgaard K, Rasmussen LM, Brixen K, Brock-Jacobsen B, Poulsen MR, Vestergaard P, Ralston SH, Albagha OME, Poulsen S, Haubek D, Gjørup H, Hintze H, Andersen MG, Heickendorff L, Hjelmborg J, Gram J Calcif Tissue Int 87:108-119, 2010

3. Martin RB, Burr D J Biomech 17;195-201, 1984

4. Beck TJ, Ruff CB, Warden KE, Scott Jr WW, Rao GU Invest Radiol 25:6-18, 1990 